九州大学学術情報リポジトリ

Kyushu University Institutional Repository

Reaction of Partially Hydrolyzed Products of Saligenin Cyclic Phosphorus Esters Toward SHCompcunds

Ohkawa, Hideo

Laboratory of Pesticide Chemistry, Faculty of Agriculture, Kyushu University

Maruo, Shigeaki

Laboratory of Pesticide Chemistry, Faculty of Agriculture, Kyushu University

Eto, Morifusa

Laboratory of Pesticide Chemistry, Faculty of Agriculture, Kyushu University

https://doi.org/10.5109/22814

出版情報 : 九州大学大学院農学研究院紀要. 17 (1)，pp.13-19，1972-08. Kyushu University バージョン：

権利関係 : 


\title{
Reaction of Partially Hydrolyzed Products of Saligenin Cyclic Phosphorus Esters Toward SH-Compcunds
}

\author{
Hideo Ohkawa ${ }^{1}$, Shigeaki Maruo ${ }^{2}$ and Morifusa Eto \\ Laboratory of Pesticide Chemistry, Faculty of Agriculture, \\ Kyushu University, Fukuoka
}

(Received December 5, 1971)

In order to know the mechanism for the alkylation of mercaptans and for the inhibition of "SH-enzymes" with saligenin cyclic phosphorus esters, a possible intermediate, that is a ring-opened salicyl ester, and related compounds including saligenin cyclic hydrogen phosphate were synthesized and their reactions with cysteine and yeast alcohol dehydrogenase were investigated. Besides neutral saligenin cyclic esters, only salicyl ester was active as alkylating agent and SH-enzyme inhibitor.

It is known that pentavalent phosphorus acid esters react with nucleophiles to alkylate as well as to phosphorylate them. Many reactions of biologically important phosphate esters are basically phosphorylation. Antiesterase and insecticidal activities of organophosphorus insecticides are also attributed to phosphorylation reaction. The important role of the alkylation reaction of phosphate esters was recognized in the biogenesis of terpenoids. The chemical and biochemical significances of alkylation reaction for organophosphorus pesticides have been discussed by us (Eto and Ohkawa, 1970).

Of the cyclic phosphorus esters of saligenin, alkyl phosphates, phosphorothionates and phosphorothiolates inhibit cholinesterase at least in vivo and show high insecticidal activity (Eto et al., 1963a, 1963b; Eto, 1969; Kobayashi et al., 1969). On the other hand, high fungicidal activity against Piricularia oryzae was observed in saligenin cyclic phosphorothiolates, but was not in corresponding insecticidal phosphate and phosphorothionate esters (Kobayashi et al., 1969).

Furthermore, it was observed that cyclic S-alkyl phosphorothiolates react with SH---group to alkylate (salicylate) mercaptans and to inhibit "SH-enzymes" like as yeast alcohol dehydrogenase (1.1.1.1 Alcohol: NAD oxidoreductase) (Eto et al., 1968; Ohkawa and Eto, 1969). Saligenin cyclic S-alkyl phosphorothiolates are readily hydrolyzable and react with mercaptans to give corresponding salicylthioethers after a considerable time lag in an aqueous condition. This suggests that the reaction proceeds via a partially hydrolyzed intermediate, i. e., salicyl ester.

This paper describes the synthesis of the possible intermediates and their

1) Present address : Research Department, Pesticide Division, Sumitomo Chemical Co., Takarazuka.

2) Present address: Rerearch Institute, Nippon Shinyaku Co., Kyoto. 
inhibitory activity toward alcohol dehydrogenase.

\section{MATERIALS AND METHODS}

Synthetic procedures for the cyclic phosphorus esters of saligenin (I, II) were reported in our previous papers (Eto et al., 1963c; Eto and Oshima, 1962; Kobayashi et al., 1969).

2-Hydroxy-4H-1, 3, 2-benzodioxaphosphorin-2-oxide (saligenin cyclic hydrogen phosphate) (III). A mixture of 2-methoxy-4H-1, 3, 2-benzodioxaphosphorin-2-oxide (2 g) and diethylamine $(20 \mathrm{ml})$ was stirred for $2 \mathrm{hr}$ at room temperature. Twenty $\mathrm{ml}$ of $2 \%$ sodium hydroxide was added to the reaction mixture and separated oil was extracted with ether. The remained aqueous solution was acidified until $\mathrm{pH} 1$ with $6 \mathrm{~N}$ hydrochloric acid and then extracted with butanol. Butanol was evaporated under reduced pressure to give crude crystals, which were purified through a Dowex $50 \times 8\left(\mathrm{H}^{+}\right)$column eluted with water. The eluate was lyophilized. M. p. $144-145^{\circ} \mathrm{C}$. Anal. Found : C, 45.14; H, 3.95. Calcd. for $\mathrm{C}_{7} \mathrm{H}_{7} \mathrm{O}_{4} \mathrm{P}: \mathrm{C}, 45.17 ; \mathrm{H}, 3.79 \%$. IR $\nu_{\max }^{\mathrm{KBr}} \mathrm{cm}^{-1}: 2500,2150,1660,1010,510,490(\mathrm{O}=$ $\mathrm{P}-\mathrm{OH})$; 1615, 1582, 1490, 1460 (aromatic ring) ; $1258(\mathrm{P}=\mathrm{O})$; 1180, 1028 (P-0-CH,) ; 1105, 956 (P-O-C aryl). NMR (in $\left.\mathrm{D}_{2} \mathrm{O}\right) \delta: 5.25\left(\mathrm{~d}, \mathrm{~J}=12 \mathrm{cps},-\mathrm{CH}_{2}-\right), 7.25$ (m, aromatic $\mathrm{H})$.

2-Phenyl-1,3, 2-benzodioxaphosphole-2-oxide (catechol cyclic phenylphosphonate) (IV). Phenylphosphonyl dichloride (10.6 g) was added dropwise to a mixture of catechol (5 g) and pyridine (10.8 g) with stirring and cooling in an ice-bath, It took $3 \mathrm{hr}$. The reaction mixture was stirred for $2 \mathrm{hr}$ at room temperature and extracted with ether. The ether solution was washed with $\mathrm{N}$ hydrochloric acid, $10 \%$ sodium hydrogen carbonate and water and then dried over anhydrous sodium sulfate. The solvent was evaporated and the residue was recrystallized from carbon tetrachloride. M. p. $215-216^{\circ} \mathrm{C}$. Anal. Found: C, 61.50; H, 4.06. Calcd. for $\mathrm{C}_{12} \mathrm{H}_{9} \mathrm{O}_{3} \mathrm{P}: \mathrm{C}, 62.08 ; \mathrm{H}, 3.91 \%$. IR $\nu \nu_{\max }^{\mathrm{CHCl}_{3}} \mathrm{~cm}^{-1}: 1600,1500$ (aromatic ring) ; 1263 $(\mathrm{P}=\mathrm{O})$; 1132, 1107, 954 (P-O-C aryl).

Salicyl hydrogen phenylphosphonate $(\mathrm{V})$. To a mixture of saligenin cyclic phenyl phosphonate $(2 \mathrm{~g})$ and acetonitrile $(15 \mathrm{ml})$ was added triethylamine $(4 \mathrm{ml})$ and water $(4 \mathrm{ml})$. After stirring for $3 \mathrm{hr}$ at room temperature, cyclohexylamine (1. $2 \mathrm{~g}$ ) was added to the reaction mixture. The yielded precipitation of cyclohexylammonium salt was filtered and recrystallized from a solvent mixture of ethanol and acetonitrile (1 : 1). M. p. $172-173^{\circ} \mathrm{C}$. Anal. Found: C, 62.65; H, 7.27; $\mathrm{N}, 3.77 ; \mathrm{P}$, 8.47. Calcd. for $\mathrm{C}_{13} \mathrm{H}_{12} \mathrm{O}_{3} \mathrm{P} \cdot \mathrm{C}_{6} \mathrm{H}_{13} \mathrm{~N}: \mathrm{C}, 62.80 ; \mathrm{H}, 7.21 ; \mathrm{N}, 3.86: \mathrm{P}, 8.52$ $\%$. IR $\nu_{\max }^{\mathrm{KBr}} \mathrm{cm}^{\prime}$ : $3450(\mathrm{OH}) ; 2950(\mathrm{CH}$,$) ; 1616, 1585, 1486$ (aromatic ring) ; 1180, 1005 (P-0-CH,) ; 1150, $1060\left(\mathrm{P} \ll_{0}^{0}\right)$.

Benzyl ethyl hydrogen phosphate (VI). This was synthesized applying the procedure of Miyano and Funahashi (1955). The mixture of dibenzyl ethyl phosphate $(8 \mathrm{~g})$ and lithium chloride $(5 \mathrm{~g})$ in ethoxyethanol $(100 \mathrm{ml})$ was heated at $107^{\circ} \mathrm{C}$ for $2.5 \mathrm{hr}$. The mixture was diluted with aqueous potassium carbonate and extracted with chloroform. The aqueous layer was acidified with sulfuric acid and extracted with ether. Ether was evaporated under reduced pressure and the residue was dissolved in acetonitrile. Cyclohexylamine was added to precipi- 
tate salt, which was recrystallized from acetonitrile. M. p. $110-111^{\circ} \mathrm{C}$. Yield $4.9 \mathrm{~g}$. The cyclohexylammonium salt was dissolved in water and subjected to Dowex $50\left(\mathrm{H}^{+}\right)$column. The eluate was lyophilized to give colorless oil. IR $\nu_{\max }^{\mathrm{CHCl}_{3}} \mathrm{~cm}-^{\prime}: 2650,2280,1660(\mathrm{O}=\mathrm{P}-\mathrm{OH}) ; 1210(\mathrm{P}=\mathrm{O}) ; 1020(\mathrm{P}-0-\mathrm{CH}) ; 1500,$,1160 , 1080, 700 (monosubstituted aromatic ring) ; $1460\left(\mathrm{CH}_{2}\right)$.

Diethyl p-methoxybenzyl phosphate (VII). This was synthesized from diethyl phosphorochloridate and anisyl alcohol in the presence of pyridine. The product decomposed at $110^{\circ} \mathrm{C}(0.002 \mathrm{mmHg})$. Then it was purified through a silicic acid

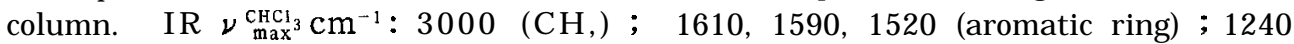
( $\mathrm{P}=\mathrm{O}$ and/or C-O-C aryl) ; 1170, 1020 (P-O-C alkyl).

0, 0-Diethyl S-benzyl phosphorothiolate (Kitazin) (VIII). Technical preparation was obtained from Kumiai Chemical Co. and was purified by distillation under reduced pressure.

Reaction with cysteine and inhibitory activity toward yeast alcohol dehydrogenase. Experiments were carried out in the same manners as described in the previous paper (Ohkawa and Eto, 1969).

Other methods. Infrared spectra were made from $10 \%$ chloroform solution or $\mathrm{KBr}$ discs with a Shimazu IR-27G infrared spectrometer. Nuclear magnetic resonance spectra were made with a Nippon Denshi JNM-3H-60 nuclear magnetic resonance spectrometer.

\section{RESULTS AND DISCUSSION}

It has been suggested that the hydrolysis of saligenin cyclic phosphoryl esters proceeds at the first stage by opening of P-O-C aryl bond in the hetero ring giving salicyl esters (Eto and Oshima, 1962). The ring-opened salicyl esters have been considered also as the intermediates in the reaction with mercaptans

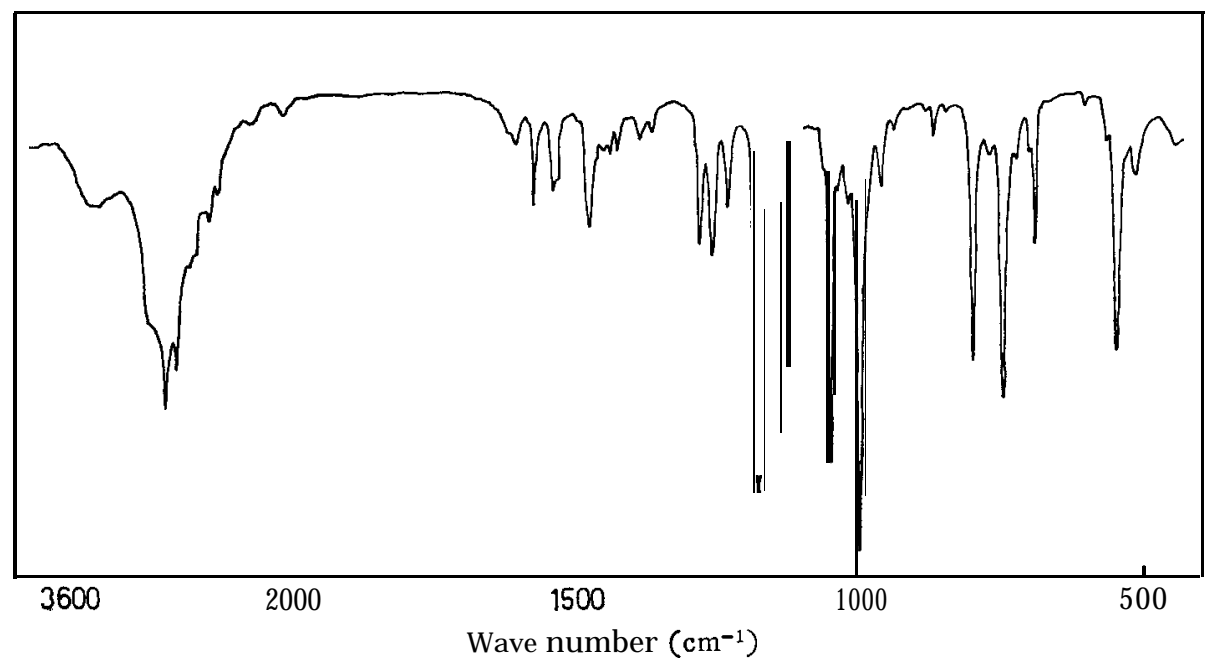

Fig. 1. Infrared absorption spectrum of cyclohexylammonium salicyl phenylphosphonate $(\mathrm{V})$. (KBr) 
(Eto et al., 1968). Salicyl hydrogen phenylphosphonate was now synthesized in order to examine its reactivity with $\mathrm{SH}$-group.

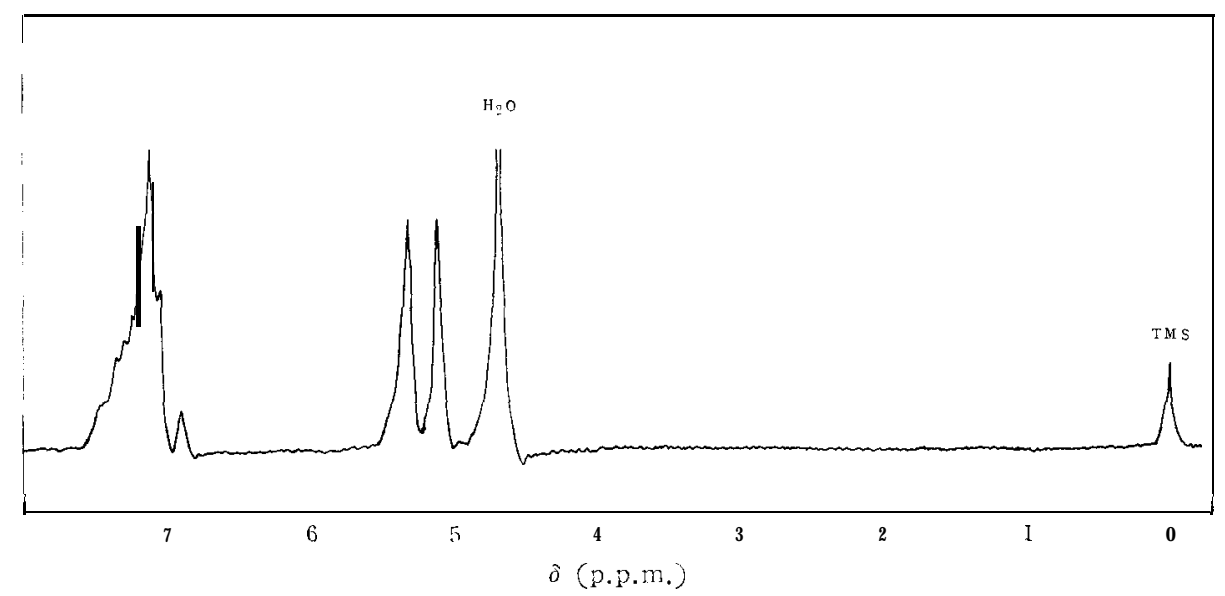

Fig. 2. Nuclear magnetic resonance spectrum of saligenin cyclic hydrogen phosphate (III) at $60 \mathrm{MC}$ in $\mathrm{D}_{2} \mathrm{O}$.

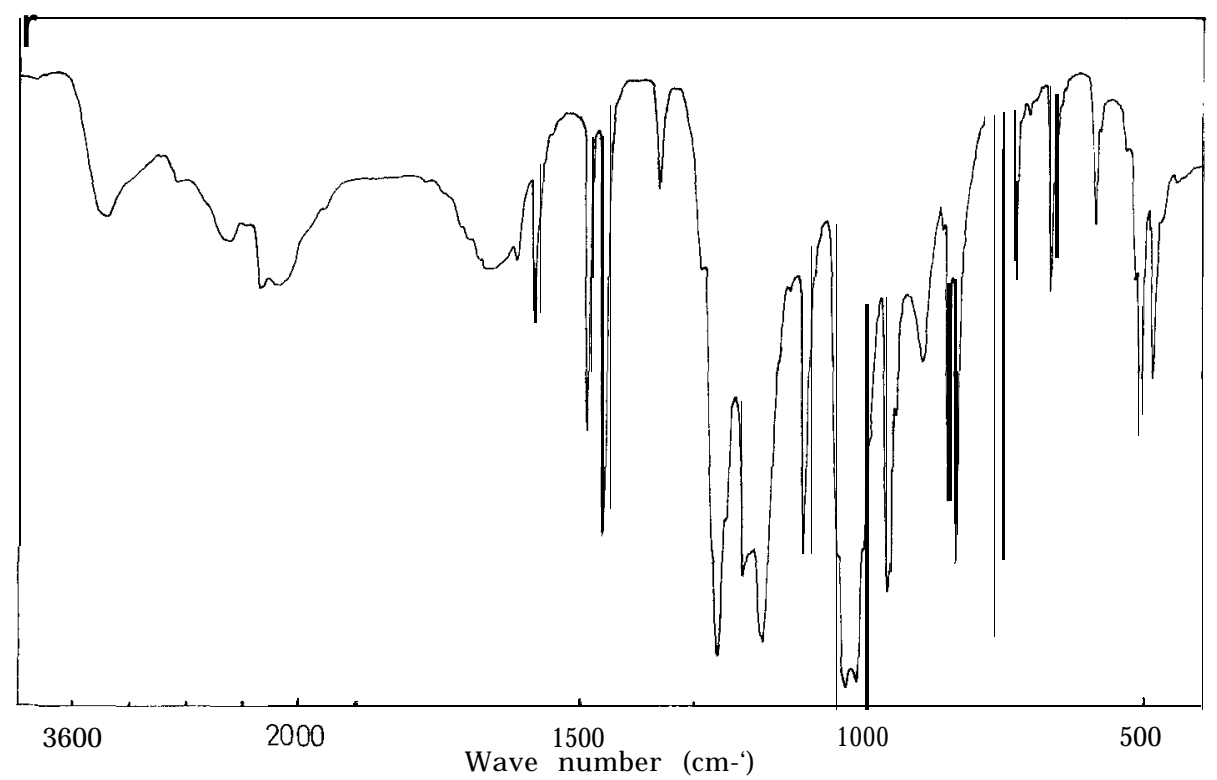

Fig. 3. Infrared absorption spectrum of saligenin cyclic hydrogen phosphate (III).

As a starting material, saligenin cyclic phenylphosphonate was choiced to prepare salicyl ester in order to avoid any confusion which would possibly occur by the formation of cyclic hydrogen phosphate, if phosphate esters were used. It was hydrolyzed in the presence of triethylamine. The hydrolyzate was isolated as cyclohexylammonium salt. The structure was confirmed by infrared absorption spectrum indicating the presence of $\mathrm{P}-0-\mathrm{CH}$, bond $\left(1180,1005 \mathrm{~cm}^{-1}\right)$ 
and the absence of P-O-C aryl bond as shown in Fig. 1. It was positive to the qualitative test of phenols such as 4-aminoantipyrine. Its aminoantipyrine derivative was chromatographically identical with that produced from partial hydrolyzate in phosphate buffer solution (Eto and Oshima, 1962).

By the action of diethylamine, saligenin cyclic methyl phosphate decomposed in two different ways; the cleavage of the hetero ring and demethylation. A demethylated product retaining the hetero ring, i. e., saligenin cyclic hydrogen phosphate, was isolated. The structure was supported by elemental analysis and spectrometries (Figs. 2 and 3). Nuclear magnetic resonance spectrum (Fig. 2) shows a signal assignable to $\mathrm{P}-0-\mathrm{CH}$, (benzyl) at $\delta 5.25(\mathrm{~d}, \mathrm{~J}=12 \mathrm{cps}$ ) and the absence of P-0-CH,. Infrared absorption spectrum (Fig. 3) shows the presence of P-O-CH, $\left(1180,1028 \mathrm{~cm}^{-1}\right), \mathrm{P}-\mathrm{O}-\mathrm{C}$ aryl $\left(1105,956 \mathrm{~cm}^{-1}\right)$ and $\mathrm{O}=\mathrm{P}-\mathrm{OH}$ $\left(2500,2150,1660,1010,510,490 \mathrm{~cm}^{-1}\right)$.

Catechol cyclic phenylphosphonate and some benzyl phosphates were also prepared for comparison with the cyclic and opened esters of saligenin.

Table 1 shows the reactivity of some cyclic and benzyl phosphoryl esters

Table 1. Reactivity with SH-group of some cyclic and benzyl phosphoryl esters.

\begin{tabular}{|c|c|c|c|}
\hline No. & Structure & \multicolumn{2}{|c|}{$\begin{array}{l}\text { Reaction with } \mathrm{I}_{50} \mathrm{ADH} * \\
\text { cysteine }{ }^{* 1}\left(\mathrm{M} \times 10^{5}\right)\end{array}$} \\
\hline I & & + & 4.5 \\
\hline II & & + & 5.0 \\
\hline III & & - & $>50(0)$ \\
\hline IV & & - & $>50(0)$ \\
\hline V & & + & $10 * 3$ \\
\hline VI & & - & $>50(0)$ \\
\hline VII & O & - & $>50(0)$ \\
\hline VIII & (0) & - & $>50(0)$ \\
\hline
\end{tabular}

*1. Thin layer chromatography was used for the detection of reaction products with cysteine.

*2. Concentration for $50 \%$ inhibition of alcohol dehydrogenase. Figures in parentheses are percentage of inhibition at $5 \times 10^{-4} \mathrm{M}$.

*3. Cyclohexylammonium salt was used. 
toward cysteine and yeast alcohol dehydrogenase. Only compounds reactive with cysteine are the effective inhibitors of alcohol dehydrogenase. The inhibition should be due to the alkylation of SH-group of the enzyme. Neutral cyclic phosphoryl esters of saligenin (I and II) are active to alkylate (salicylate) SHgroup of cysteine and to inhibit alcohol dehydrogenase. However, cyclic ester structure is not essential for the reactivity: cyclic hydrogen phosphate ester (III) is completely inactive toward cysteine and the dehydrogenase. This may be due to the decrease in electrophilic reactivity of phosphorus by dissociation. As cyclic phenylphosphonate (II) having a stable $\mathrm{P}-\mathrm{C}$ bond is active, the inhibition of alcohol dehydrogenase should not be attributed to the reaction of exocyclic substituent group of phosphorus.

Catechol cyclic phenylphosphonate is inactive, suggesting the necessity of benzyl ester group for the reactivity with SH-group. A non-cyclic phosphoryl ester of saligenin, salicyl phenylphosphonate (V), is as active as neutral saligenin cyclic esters, although it has a dissociable hydrogen. It reacted rapidly with cysteine to give S-salicylcysteine, which was characterized in comparison with an authentic compound obtained from the reaction of $\boldsymbol{o}$-acetoxybenzyl chloride and cysteine (Ohkawa and Eto, 1969). Its inhibitory activity against alcohol dehydrogenase is slightly less than corresponding cyclic neutral ester (II). This may be caused by the interference of cyclohexylamine: it reacts to yield $\mathrm{N}$ salicylcyclohexylamine (Eto et al., 1971).

Combined these observations support that salicyl phosphoryl esters are the intermediate in the course of reaction between saligenin cycic phosphoryl esters and SH-compounds in aqueous conditions (Fig. 4).

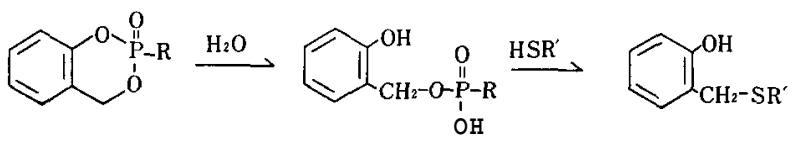

Fig. 4. Reaction between saligenin cyclic phosphoryl esters and SH-compounds in aqueous condition.

For the alkylation reaction of benzyl esters toward SH-group, a strong electron releasing group such as hydroxyl group is necessary. Hydroxyl group at ortho position may promote the formation of benzyl carbonium ion, which may actually react with $\mathrm{SH}$-group to give thioether. Methoxyl group appears to be not enough for the activation of benzyl ester group; diethyl p-methoxybenzyl phosphate (VII) is inactive against alcohol dehydrogenase, though it was active as inhibitor against another SH-enzyme papain at higher concentration $\left(5 \times 10^{-3} \mathrm{M}\right)$ (Ohkawa and Eto, 1969).

0, 0-Diethyl S-benyl phosphorothiolate (VIII) known as fungicide (Kitazin) is not active as alkylating agent in vitro. However, the in vivo conversion of Sbenzyl phosphorothiolate into ring-hydroxylated metabolite may be presumable.

Some groups of phosphate esters other than presented saligenin derivatives were also examined to find the inhibitors of "SH-enzymes" and it was found that p-hydroxyphenyl phosphates and their thiolate analogs were active as the inhibitors of alcohol dehydrogenase. This will be reported in detail elsewhere. 


\section{ACKNOWLEDGEMENTS}

This work was supported in part by a grant from the Ministry of Education. The authors thank to Prof. K. Maekawa for his encouragement and to Prof. G. Tomita for his kind help in the measurement of NMR spectra.

\section{REFERENCES}

Eto, M. 1969. Specificity and mechanism in the action of saligenin cyclic phosphorus esters. Residue Reviews, 25 : 187-200.

Eto, M., K. Hanada, Y. Namazu and Y. Oshima, 1963a. The correlation between antiesterase activity and chemical structure of saligenin cyclic phosphates. Agr. Biol. Chem., $27:$ 723-727.

Eto, M., Y. Kinoshita, T. Kato and Y. Oshima, 1963b. Saligenin cyclic methyl phosphate and its thiono analogue: new insecticides related to the active metabolite of tri-o-cresyl phosphate. Nature, 200:171-172.

— 1963 c. Saligenin cyclic alkyl phosphates and phosphorothionates with insecticidal activity. Agr. Biol. Chem., 27: 789-794,

Eto, M., and H. Ohkawa, 1970. Alkylation reaction of organophosphorus pesticides : Its chemical and biochemical significances. Biocohemical Toxicology of Insecticides, ed. R. D. O'Brien and I. Yamamoto, Academic Press, pp. 93-104.

Eto, M., H. Ohkawa,, K. Kobayashi and T. Hosoi, 1968. Saligenin cyclic phosphorus esters as biological alkylating agents and fungicides. Agr. Biol. Chem., 32: 1056-1058.

Eto, M., and Y. Oshima, 1962. Synthesis and degradation of cyclic phosphorus esters derived from saligenin and its analogues. Agr. Biol. Chem., 26: 452-459.

Eto, M., M. Sasaki, M. Iio, M. Eto and H. Ohkawa, 1971. Synthesis of 2-methylthio-4H-1, 3, 2-benzodioxaphosphorin-2-oxide by thiono-thiol conversion and its use as phosphorylating agent. Tetrahedron Letters, No. 45, 4263-4266.

Kobayashi, K., M. Eto, Y. Oshima, T. Hirano, T. Hosoi and S. Wakamori, 1969. Synthesis and biological activities as insecticides and fungicides of saligenin cyclic phosphorothiolates. Botyu-Kagaku, 34 : 165-170.

Miyano, M. and S. Funahashi, 1955. Synthesis of organic phosphorus compounds. II. Exhaustive debenzylation reactions. J. Am. Chem. Soc., $77: 3524-3526$.

Ohkawa, H. and M. Eto, 1969. Alkylation of mercaptans and inhibition of "SH-enzymes" by saligenin cyclic phosphate and phosphorothiolate esters. Agr. Biol. Chem., 33: 443-451. 